\title{
Relationships between soil water repellency and microbial community composition under different plant species in a Mediterranean semiarid forest
}

\author{
Elena Lozano $^{1 *}$, Fuensanta García-Orenes ${ }^{1}$, Gema Bárcenas-Moreno ${ }^{2}$, Patricia Jiménez-Pinilla ${ }^{1}$, Jorge \\ Mataix-Solera ${ }^{1}$, Victoria Arcenegui ${ }^{1}$, Alicia Morugán-Coronado ${ }^{3}$, Jorge Mataix-Beneyto ${ }^{1}$ \\ ${ }^{1}$ GEA (Grupo de Edafología Ambiental). Departamento de Agroquímica y Medio Ambiente, Universidad Miguel Hernández, Avenida de \\ la Universidad s/n, 03202 Elche, Alicante, Spain. \\ ${ }^{2}$ MEDSoil Research Group, Departamento de Cristalografía, Mineralogía y Química Agrícola, Facultad de Química, Universidad de \\ Sevilla, Spain. \\ ${ }^{3}$ SEDER, Department of Geography, University of Valencia, Blasco Ibañez, 28, 46010-Valencia, Spain. \\ * Corresponding author. E-mail: elozano@umh.es
}

\begin{abstract}
Soil water repellency (SWR) can influence many hydrological soil properties, including water infiltration, uneven moisture distribution or water retention. In the current study we investigated how variable SWR persistence in the field is related to the soil microbial community under different plant species (P. halepensis, $Q$. rotundifolia, $C$. albidus and R. officinalis) in a Mediterranean forest. The soil microbial community was determined through phospholipid fatty acids (PLFA). The relationships between microbiological community structure and the soil properties $\mathrm{pH}$, Glomalin Related Soil Protein (GRSP) and soil organic matter (SOM) content were also studied. Different statistical analyses were used: Principal Component Analysis (PCA), ANOVA, Redundancy Analysis and Pearson correlations. The highest concentrations of PLFA were found in the most water repellent samples. PCA showed that microorganism composition was more dependent of the severity of SWR than the type of plant species. In the Redundancy Analysis, SWR was the only significant factor $(\mathrm{p}<0.05)$ to explain PLFA distributions. The only PLFA biomarkers directly related to SWR were associated with Actinobacteria (10Me16:0, 10Me17:0 and 10Me18:0). All the results suggest that a strong dependence between SWR and microbial community composition.
\end{abstract}

Keywords: Soil hydrophobicity; Phospholipids fatty acids; Microbial community structure; Biohydrology; Actinobacteria; Glomalin Related Soil Protein.

\section{INTRODUCTION}

Soil water repellency (SWR) can greatly influence the hydrology and the ecology of forest soils. The hydrological implications of SWR include reduced infiltration rates, enhanced runoff and overland flow that can exacerbate erosion and possibly flood risk (Cerdà et al., 1998; Coelho et al., 2005; DeBano et al., 2000; Doerr et al. 2000; Lichner et al., 2013; Moral García et al., 2005; Nicolau et al., 1996). SWR can also affect ecological processes including an allelopathic effect by suppressing the germination of competing vegetation (Stevens and Tang, 1985), and the improvement of water conservation into the soil profile by penetration to depth through preferential flow pathways (Moore and Blackwell, 1998; Robinson et al., 2010) and decreased evaporation rates through hydrophobic surface soils (Hallett, 2007). The origin of SWR has been researched in many studies, and although the role of soil microorganisms has been appreciated for many years (Bond and Harris, 1964), data on the interaction between SWR and soil microbial structure are scarce.

SWR, soil microbiology structure and activity are all functions of abiotic and biotic conditions; soil texture and mineralogy, soil moisture, climate, site specific conditions, chemical parameters, substrate availability, land use and plant communities (Gömöryová et al., 2013; Merilä et al., 2010; White et al. 2005; Zornoza et al., 2009). Previous research has shown that water repellent patches of soil differ from adjacent wettable soils in $\mathrm{pH}$, moisture, SOM quality and quantity, and microbial biomass (Doerr et al., 2000), even beneath the same plant species (Lozano et al., 2013). When soil microorganisms decompose SOM, hydrophilic compounds are more readily degraded, potentially resulting in an accumulation of hydrophobic compounds over time. The capacity of soil microorganisms to degrade different SOM compounds depends upon species composition, so this may affect changes in SWR at the microsite scale (such as the presence of soil water repellent patches) (Müller et al., 2010). Early studies suggest that SWR might be caused by substances produced by the activity of certain fungi species (Savage et al., 1969). Based on these assumptions, the microbiology structure in soil samples with different SWR persistence and under different plant species was studied for a Mediterranean semi-arid forest where SWR is known to occur.

This contribution is a continuation of previous research (Lozano et al., 2013), where we concluded that the quality of $\mathrm{SOM}$, in specific a lipid fraction, could be the main factor involved in SWR. However, in the case of forested land with Pinus, it was also postulated that soil microbiology could be another major factor, but this was not investigated. In the current study, microbial community structure measured with phospholipid fatty acid (PLFA) analysis, was compared to the persistence of SWR. The sites studied are the same as Lozano et al. (2013), which were in a Mediterranean climate and under trees (Pinus or Quercus), or shrubs. A patchy distribution of SWR was found by (Lozano et al., 2013), so the sites were 
Table 1. Soil properties of the different samples used in the study.

\begin{tabular}{|c|c|c|c|c|c|c|}
\hline Soil sample & $\begin{array}{c}\text { WDPT } \\
\text { (s) }\end{array}$ & $\begin{array}{c}\text { Log WDPT } \\
\text { (s) }\end{array}$ & WR class & $\mathrm{pH}$ & $\begin{array}{l}\text { SOM } \\
(\%)\end{array}$ & $\begin{array}{c}\text { GRSP } \\
(\mu \mathrm{g} \text { prot/g soil) }\end{array}$ \\
\hline Quercus 1 & 498 & 2.70 & Strong $(++)$ & 7.8 & 17.0 & 43.4 \\
\hline Quercus 2 & 1623 & 3.21 & Strong $(++)$ & 8.1 & 16.9 & 41.1 \\
\hline Quercus 3 & 5.1 & 0.73 & Slight $(+)$ & 8.0 & 13.4 & 42.4 \\
\hline Pinus 1 & 7 & 0.85 & Slight $(+)$ & 7.9 & 12.4 & 35.3 \\
\hline Pinus 2 & 6.8 & 0.83 & Slight $(+)$ & 7.9 & 11.3 & 32.0 \\
\hline Pinus 3 & 7.3 & 0.86 & Slight $(+)$ & 8.0 & 11.5 & 37.1 \\
\hline Cistus 1 & 1 & 0.10 & Wettable (-) & 8.2 & 5.3 & 27.3 \\
\hline Cistus 2 & 1 & 0.10 & Wettable (-) & 8.1 & 7.1 & 28.6 \\
\hline Cistus 3 & 1 & 0.10 & Wettable (-) & 8.1 & 5.9 & 24.9 \\
\hline Rosmarinus 1 & 1 & 0.10 & Wettable (-) & 8.0 & 6.5 & 32.2 \\
\hline Rosmarinus 2 & 21.25 & 1.33 & Strong $(++)$ & 7.9 & 15.2 & 50.1 \\
\hline Rosmarinus 3 & 13.25 & 1.12 & Strong $(++)$ & 8.0 & 13.3 & 42.7 \\
\hline
\end{tabular}

WDPT: Water Drop Penetration Time; WR: Water Repellency; SOM: Soil Organic Matter content; GRSP; Glomalin Related Soil Protein.

sampled at different locations to give a range of SWR severity that could then be measured for microbial community structure. Studying soil microbiology structure might help to understand the possible influence of SWR in soil microbiology, or in contrast, the possible influence of soil microbiology in the development of SWR. Understanding of the relationship is of great ecological importance, especially given that Pinus $s p$. has been closely related to SWR (Lozano et al., 2013; Mataix Solera et al., 2007) and is commonly used in afforestation projects.

\section{MATERIALS AND METHODS \\ Study area}

The study area is located in the 'Sierra de la Taja' $\left(38^{\circ} 23^{\prime} \mathrm{N}\right.$; $0^{\circ} 59^{\prime} \mathrm{W}$ ) near Pinoso, in the province of Alicante (SE Spain). The region has a semi-arid Mediterranean climate with a mean annual precipitation of $277.5 \mathrm{~mm}$ and a mean annual temperature of $15.8^{\circ} \mathrm{C}$ ranging from $7.8^{\circ} \mathrm{C}$ in January to $24.1^{\circ} \mathrm{C}$ in August (average 1980-2010). The area of the 'Sierra de la Taja' is approximately 500 ha. Soil samples were taken under similar conditions with respect to soil type, geology, plant distribution and slope. The soil is a Lithic Xerorthent (Soil Survey Staff, 2006) with a calcareous nature developed over Jurassic limestone. The soil texture in the area is loam, with $36 \%$ sand, $49 \%$ silt and $15 \%$ clay.

Three types of vegetation covered the area: (i) Pinus halepensis Miller (approximately 40 years old), (ii) Quercus rotundifonlia and (iii) shrub perennial vegetation comprised mainly Quercus coccifera L., Rosmarinus officinalis L., Juniperus oxycedrus L., Cistus albidus L., Brachypodium retusum Pers. (Beauv.), Stipa tenaccissima L. and Pistacia lentiscus L. Tree and shrub species are mixed in the study area, but as a consequence of the relatively low density of vegetation, it was possible to carry out sampling that avoided interference between the different species.

\section{Soil sampling}

Samples were taken in September 2011, when the SWR is expected to be at its peak after the typical Mediterranean summer drought (Doerr et al., 2000). Soils were sampled from the first $2.5 \mathrm{~cm}$ of the A horizon at microsites (approximately 100 $\left.\mathrm{cm}^{2}\right)$ beneath each of the four most representative species $(\mathrm{Pi}$ nus halepensis, Rosmarinus officinalis, Quercus rotundifolia and Cistus albidus; $\mathrm{n}=15$ per species). Both plants and microsites under each plant were randomly selected within a $100 \mathrm{~m} \mathrm{x}$ $100 \mathrm{~m}$ area. Based on water repellency results, we selected three soil samples per species for PLFAs analysis, including the variability of SWR classes found in some cases per species when possible (e.g. Rosmarinus and Quercus). We analysed the relationships between PLFAs with soil properties related with SWR such as: soil organic matter (SOM) content (Martínez-Zavala and Jordán López, 2009), glomalin related soil protein (Rillig, 2005) and pH (Lozano et al., 2013; Mataix-Solera et al., 2007).

\section{Laboratory methods}

Soil samples were dried at room temperature $\left(20-25^{\circ} \mathrm{C}\right)$ to a constant weight and passed through a $2 \mathrm{~mm}$ sieve to remove coarse soil particles before soil analysis. Soil $\mathrm{pH}$ was measured in aqueous soil extract in de-ionised water $(1: 2.5 \mathrm{w}: \mathrm{s})$ at $25^{\circ} \mathrm{C}$. SOM content was analysed by rapid dichromate oxidation of organic carbon (Nelson and Sommers, 1996). The persistence of SWR was measured by the Water Drop Penetration Time (WDPT) test (King, 1981). The logarithm of the WDPT value in seconds was used and samples were taken as water repellent if the value of $\log$ (WDPT) was >0.7. Based on the SWR of the 12 samples analysed, they were divided in three groups; strong $(\log ($ WDPT $)>1)$, slight $(\log ($ WDPT $)>0.7$ and $<0.9)$ and wettable $(\log ($ WDPT $)<0.7)$ (Table 1).

Glomalin Related Soil Protein (GRSP) is a glycoprotein produced primarily by arbuscular mycorrhizal fungi (AMF) and is contained within their hyphae walls (Wright and Upadhyaya, 
1996). When the AM hyphae die and decompose, they are thought to leave a glomalin residue in the soil (Treseder and Turner, 2007). GRSP was measured as the Easily Extractable Glomalin, which corresponded to the fraction of protein most recently deposited into the soil. GRSP was extracted from 0.25 g subsamples of soil with $2 \mathrm{ml}$ citric acid buffer, $\mathrm{pH} 7.0$ at $121^{\circ} \mathrm{C}$ for $30 \mathrm{~min}$. Protein in the supernatant was determined by a Bradford assay (Wright and Upadhyaya, 1996).

Phospholipid fatty acids (PLFA) analysis was carried out as described in Bossio et al. (1998). Briefly, fatty acids were extracted from $8 \mathrm{~g}$ soil using chloroform:methanol: phosphate buffer. They were then separated from neutral and glycolipid fatty acids on a solid phase extraction column ( $0.58 \mathrm{Si}$; Supelco Inc., Bellafonte, PA, USA). After mild alkaline methanolysis, samples were analyzed using a Hewlett Packard 6890 Gas Chromatograph with $25 \mathrm{~m}$ Ultra 2 (5\% phenyl)methylpolysiloxane column (J and W Scientific, Folsom, CA, USA). Fatty acids were quantified by comparison of the peak areas with those of an internal standard 19:0 peak. The peaks were identified using bacterial standards and identification software from the Microbial Identification System (Microbial ID, Inc., Newark, DE, USA), with 48 fatty acids identified.

Fatty acids nomenclature used was that described by Frostegåard et al. (1993). The fatty acids i15:0, 15:0, a15:0,

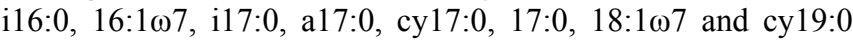
were chosen to represent bacteria (Frostegård et al., 1993). The

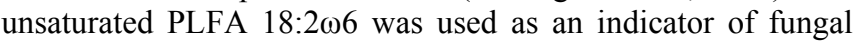

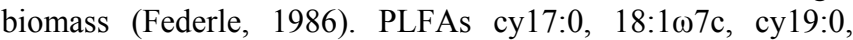
$17: 1 \omega 9 \mathrm{c}, 16: 1 \omega 9 \mathrm{c}, 18: 1 \omega 9 \mathrm{c}$ and $15: 1 \omega 4 \mathrm{c}$ were chosen to represent Gram-negative [G-] bacteria (Zelles et al., 1994). The branched, saturated i14:0, i15:0, a15:0, i16:0, i17:0 and a17:0 were chosen to represent Gram-positive $[\mathrm{G}+]$ bacteria (Zelles et al., 1994). The PLFA 10Me16:0, 10Me17:0 and 10Me18:0 were selected as indicators of actinobacteria (Zelles et al., 1994). The PLFA 16:1 15 was used as indicator of vesicular-arbuscular mycorrhizal (VAM) fungi (Olsson et al., 1995) but has also been found in bacteria (Nichols et al., 1986). The total biomass was estimated as the sum of all the extracted PLFA (total PLFA). The ratio PLFA / SOM was calculated.

\section{Statistical analyses}

Principal Components Analysis (PCA) was carried out using MVSP 3.2 (Multivariate Statistical Package, Kovach Computing) to analyze the importance of different PLFA for different species and soil WR class. Normality and homogeneity of variances for all data were tested, and log transformation was made for WDPT results. In addition, a Redundancy Analysis (RDA) was used to explore the relationship between the microbial community composition and soil characteristics. Samples with similar PLFA profiles have similar scores and will therefore group closer together when plotted. Soil properties were tested for significant contributions to the variation in the PLFA data using the Monte Carlo permutation test $(\mathrm{P}<0.05)$. Soil properties are represented by vectors distributed on 2 axis. The correlation with the axis is measured by both angle with the axis and magnitude of the vectors. Small angle and great magnitude means a great correlation. RDA can be influenced by rare fatty acids. Fatty acids that only appear in a few samples are usually unreliably represented, as their values are near the detection limit. Hence, fatty acids that were present in less than $25 \%$ of the samples were omitted to avoid this problem in developing the analysis. RDA was performed using CANOCO for Windows, Version 4.54. ANOVA-one way was also used to evaluate the differences in the ratio PLFA $\mathrm{nmol} / \mathrm{g}$ soil and SOM content (g $100 \mathrm{~g}^{-1}$ soil) between the three SWR classes. Pearson's correlation coefficients ( $r$ ) were calculated to quantify the linear relationship between soil parameters and PLFA biomarkers. Statistical analyses were performed using the SPSS 11.5 package (C SPSS Inc, 1989).

\section{RESULTS \\ Microbial community structure}

PLFA data from the soil under the four plant species were subjected to PCA. Fig. 1 shows the distribution of PC scores on the first two axes. PC1 explained $39 \%$ of the variance in PLFA composition, while PC2 explained a further $20 \%$.
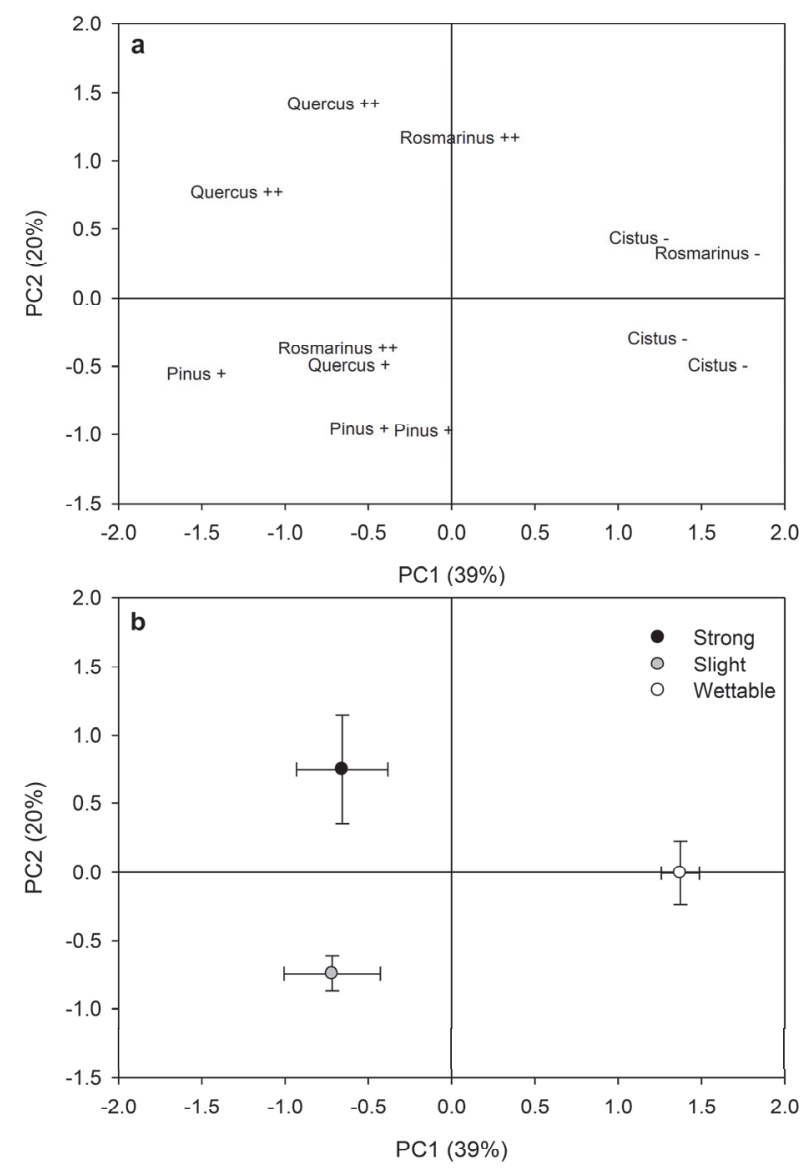

Fig. 1. Scores of the first two principal components (PCs) analyses of the phospholipid fatty acids (PLFAs): (a) distribution of the scores of the different species and their WR class, (b) distribution of samples according to the WR class; values represented correspond with the means and standard errors of the scores of each class. The different symbols indicate the WR classes; $(-)=$ wettable, $(+)=$ slight and $(++)=$ strong WR.

To determine whether plant species or SWR explains the results, PCA scores were represented in both plant species and SWR classes (Fig. 1(a) and (b)). Variations in PLFA composition were clearly explained when samples were separated by WR class (Fig. 1(a) and (b)). Axis 1 separated almost all the samples into water repellent and wettable, while axis 2 separated strong from slight water repellent and wettable samples. However, the separation between species was just clear for Pinus and Cistus in Axis 1.The RDA performed on all data (Fig. 2 ) showed that the first two axes explained $88.3 \%$ of the total 

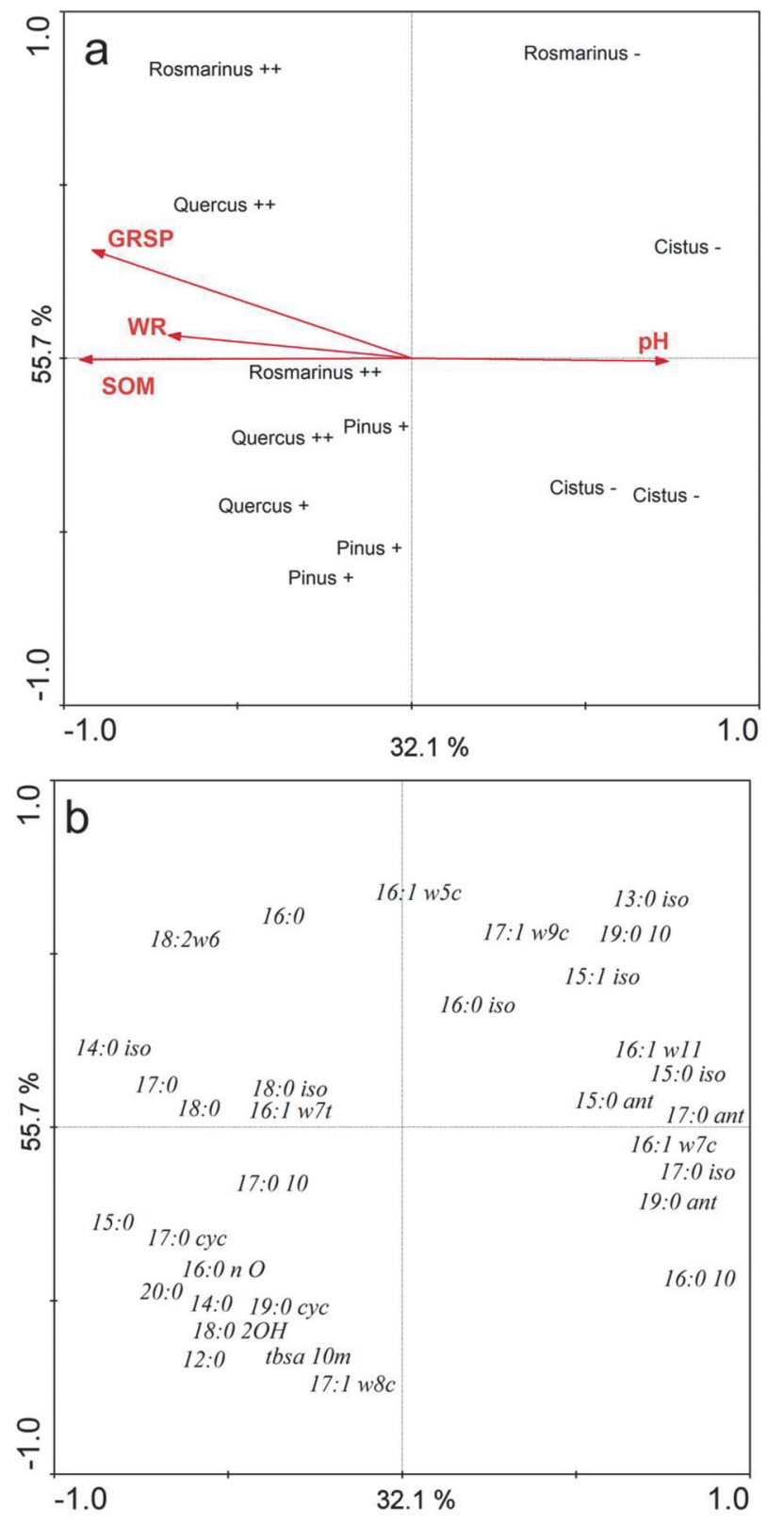

Fig. 2. Samples and soil characteristics biplots (a) and loadings plots (b) from RDA performed on the relative concentration of PLFAs in soils under the different species studied: Quercus, Pinus, Cistus and Rosmarinus. SOM: soil organic matter; WR: water repellency.

variation. Axis 1 separated WR samples from wettable samples and explained $32.1 \%$ of the variation, whilst Axis 2 explained $56.2 \%$ of the variation. The variables GRSP, SWR and SOM accounted for a large amount of the variation in the distribution along Axis 1 and thus with samples that showed water repellency. However, only the SWR variable was significant $(p<0.05)$ in explaining the PLFA data. In contrast $\mathrm{pH}$ was not associated with these soils (Fig. 2(a)). Vectors defining the axis are strongly related with the PLFA which appears in that axis (Ter Braak, 1987). Certain PLFAs were strongly associated with water repellent samples, which were characterized by high concentrations of the saturated PLFAs 14:0, 15:0, 16:0, 17:0, 18:0, 20:0 and 18:02OH, as well as the unsaturated PLFAs i14:0, 16:1w7t and cy 17:0 that are mainly representative of bacteria (Fig. 2(b)). The PLFA 18:2w6, representative of fungi, was also associated with these samples. These samples were clustered with metilated PLFAs 10Me17:0 and 10Me18:0 which are indicators of actinobacteria.

\section{Total PLFA content}

Significant differences in total PLFA content were found between water repellent and wettable samples. The highest concentrations were found in water repellent soil samples (Fig. 3(a)). Nevertheless, the greater content of microbial PLFA per $g$ of SOM content was found in wettable samples. The contents of microbial PLFA in strongly and slightly water repellent soil samples were similar (Fig. 3(b)).
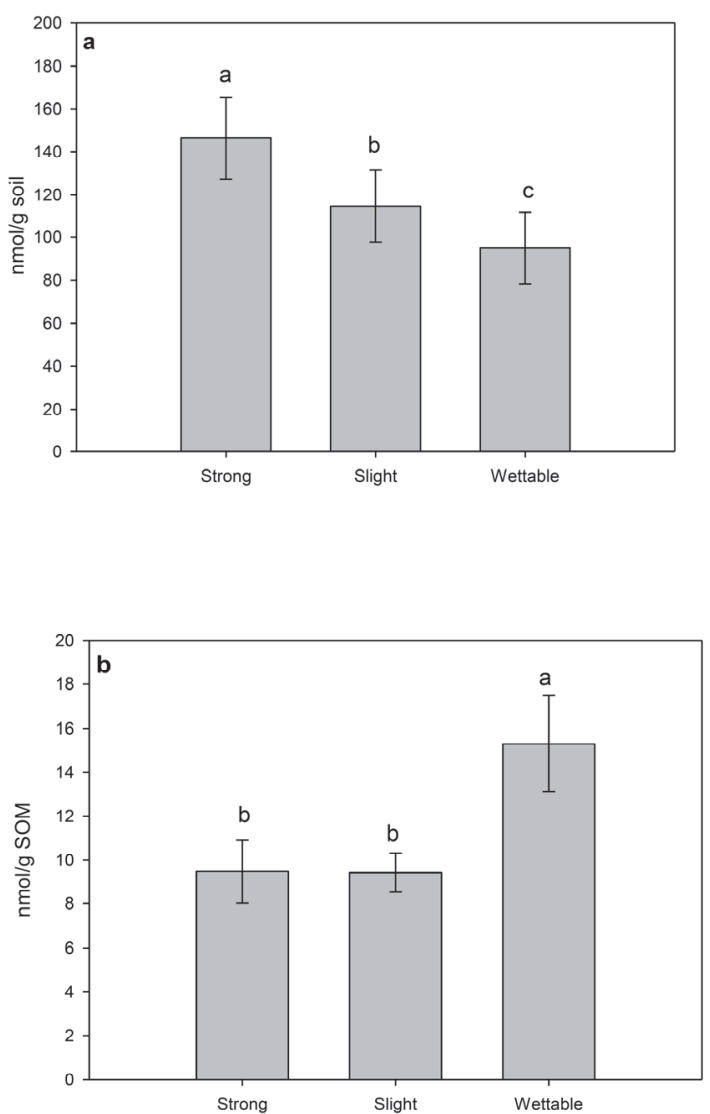

WR Class

Fig. 3. (a) Total PLFAs content (nmol/g soil) in samples grouped by the different soil WR class. (b) Total PLFAs content (nmol/g SOM) for samples grouped by the different soil WR class. Standard errors in bars. Different letters show the statistically significant differences between the different soil WR classes determined with the Tukey test $(\mathrm{P} \leq 0.05)$.

\section{Biomarkers and its relationship with environmental param- eters}

Significant correlations were found between physicochemical parameters and biomarkers (Table 2). WR was correlated with actinobacteria and total PLFAs. SOM content was correlated with all the parameters with the exception of Grampositive bacteria. However, all the parameters were strongly correlated with GRSP. No correlations were found with $\mathrm{pH}$. 
Table 2. Pearson's correlation coefficients of PLFAs biomarkers with other soil parameters.

\begin{tabular}{lcccccc}
\hline & Bact/Fung & Gram + & Gram - & Actinobacteria & Fungi & Total \\
\hline LogWDPT & 0.359 & 0.573 & 0.523 & $\mathbf{0 . 6 7 6}^{*}$ & 0.451 & $\mathbf{0 . 6 0 8}^{*}$ \\
SOM & $\mathbf{0 . 8 1 1}^{* *}$ & 0.526 & $\mathbf{0 . 7 3 2}^{* * *}$ & $\mathbf{0 . 7 5 8}^{* *}$ & $\mathbf{0 . 6 3 8}^{* *}$ & $\mathbf{0 . 7 3 6}^{* *}$ \\
GRSP & $\mathbf{0 . 9 1 3}^{* *}$ & $\mathbf{0 . 6 7 0}$ & $\mathbf{0 . 8 9 6}^{* * *}$ & $\mathbf{0 . 6 2 3}^{*}$ & $\mathbf{0 . 7 9 7}^{* *}$ & $\mathbf{0 . 7 8 2}^{* *}$ \\
pH & -0.497 & -0.516 & -0.389 & -0.514 & -0.524 & -0.507 \\
\hline
\end{tabular}

WDPT: Water Drop Penetration Time; WR: Water Repellency; SOM: Soil Organic Matter content; GRSP; Glomalin Related Soil Protein; $* * *, * * * ;$ significant differences at $\mathrm{P} \leq 0.001,0.01$ and 0.05 , respectively.

\section{DISCUSSION}

The results of this study indicate that for the calcareous soil in semiarid conditions that was studied, patterns in soil microbial community structure were clearly grouped better by SWR class than by plant species. Soil water repellent samples were more similar in microorganism composition between themselves than from samples within the same plant species (Fig. 1). This is not unusual in the Mediterranean region, where vegetation patterns exhibit a high spatial heterogeneity (Valladares et al., 2002) comprising a mixture of trees and shrubs that may interact. However, the patchy distribution of soil WR seems to influence the microbial community structure, including the prevalence of specific groups of microorganisms like actinobacteria, more than vegetation in our study. This finding is supported by Brockett et al. (2012), who found soil moisture and SOM to be more important than vegetation for soil microbial community than broad biogeographical regions. Their study was carried out in a Canadian forest, where climate and possibly the prevalence of SWR would be very different than the Mediterranean site that we studied. The interaction between SWR and soil moisture is complex (Doerr et al., 2000), and to our knowledge the interplay between these properties and the development of soil microbial structure has not been examined to date. There is a challenge to understand if microbial community structure is driven by or drives SWR. As biological impacts on SWR occur at the microscale (Rillig et al., 2005; Roper, 2004), small-scale measurements could disentangle spatial variation across millimeter resolution that may drive different microbial communities over small distances.

Many studies have found plant species composition to be a good indicator of belowground community composition (Mitchell et al. 2010; Thoms et al., 2010). In these studies the differences between plants of the same species cannot be distinguished, replicates of samples were combined for microbiological analysis, so differences found represent the general influence of tree species in a large area. However, our results are not in complete disagreement as SWR persistence is closely related to SOM content and quality, which in turn is dependent on vegetation cover (Lozano et al., 2013; Mataix-Solera et al., 2007). The influence of the dominant plant species on the input of SOM to soils is mainly attributed to the different amount and chemical composition of litter and root exudates (Graystone et al., 1996; Zak et al., 2003). Nevertheless, SWR has a patchy distribution even under the same vegetation cover type (Martínez-Zavala and Jordán-López, 2009), and this seems to influence soil microbial structure. Hydrophobic compounds of SOM may derive directly from the decomposition of plant leaves that contain considerable amounts of waxes, aromatic oils, resins and other hydrophobic substances (Doerr et al., 2000), which are generally more resistant to microbial degradation than hydrophilic ones. These hydrophobic compounds may select for microorganisms capable of producing enzymes to utilize them in soil.

Our results agree with the hypothesis about SWR as an obesity syndrome proposed by Müller and Deurer (2011). The appearance of hydrophobicity in the soil is due to the accumulation of hydrophobic substances in soil at a higher rate than its capacity of degradation. The smallest microorganism / SOM content ratio was found under the water repellent samples (Fig. $3(b))$. These results might indicate that the input of organic matter is impairing the input of microorganism biomass (SOM content increases faster than the microorganisms), which implies disequilibrium in the mineralization rates. This may produce shifts in the microbial community. Many studies point out the important role of biotic factors (microbial community structure and activity) in SOM mineralization, in addition to the environmental conditions and organic matter content (Blagodatsky et al., 2010; Garcia-Pausas and Paterson, 2011).

The persistence of SWR depends, in part, on the presence of microorganisms capable of degrading water repellent compounds. In our soil samples, actinobacteria seemed to be the only group directly correlated to SWR (Table 2). The results obtained in the study of Roper (2004), in which wax degrading bacteria were isolated and identified from water repellent soils, showed that a significant proportion of the wax-degrading bacteria belonged to actinobacteria. Many of these microorganisms have the potential to degrade waxes that cause SWR through the production of surface active molecules that facilitate their degradation (Roper, 2004). However, many PLFA mainly from bacteria were clustered with water repellent samples (Fig. 2(b)). These PLFA might have been present in a higher concentration in specific bacteria, which may have been important in the degradation of water repellent compounds. These bacteria may correspond to another bacteria isolated by Roper (2004), which did not correspond to actinobacteria.

No significant correlation has been found between the $\mathrm{pH}$ and the PLFA biomarkers in our results. This is different to a number of studies that identified soil $\mathrm{pH}$ as one of the main environmental factors driving soil microorganisms functions and structure (Bääth and Anderson 2003; Hackl et al., 2005; Högberg et al., 2007). However, the range of the $\mathrm{pH}$ values in our soils is very low (7.8-8.2) which is probably the main reason for the lack of the significant correlations.

The development of SWR from the metabolic products of micoorganism activity was first demonstrated decades ago (Bond and Harris, 1964) and SWR development has also been directly related to certain fungi species (Rillig et al., 2005; Savage et al., 1964; White et al., 2000). In our research we found a relationship between field SWR and microbial commu- 
nity structure, particularly actinobacteria. The underlying mechanisms driving this relationship needs further study as it could not be concluded whether SWR was a product of the microbial community or vice versa.

\section{CONCLUSIONS}

In the Mediterranean forest context, SWR was found to be related to microbial community composition. The accumulation of different hydrophobic compounds might be causing the shifts in microbial community structure or the soil microbial structure could be conditioned by the presence of SWR. Differences in the soil parameters (moisture, temperature, GRSP accumulated, quality of SOM) at the spatial microscale might be also responsible for the shifts in the microbial community composition, due to their role in the SOM mineralization. Our results suggest that actinobacteria are predominant in SWR samples, so further investigation of their impact on SWR development or competitive ability in water repellent soils might unravel underlying processes. We provided further evidence that soil hydrology and microbial communities are closely linked properties in soils.

Acknowledgements. The authors wish to thank the Spanish Ministry of Science and Innovation for funding through the HYDFIRE project CGL2010-21670-C02-01, and Frances Young for improving the English. Elena Lozano and Patricia Jiménez-Pinilla acknowledge the "Generalitat Valenciana" and the "Ministerio de Economía y Competitividad" of Spain for their respective grants. We thank three anonymous reviewers who provided very useful comments that improved the manuscript.

\section{REFERENCES}

Bääth, E., Anderson, T.H., 2003. Comparison of soil fungal/bacterial ratios in a $\mathrm{pH}$ gradient using physiological and PLFA-based techniques. Soil Biol. Biochem., 35, 955-963.

Blagodatsky, S., Blagodatskaya, E., Yuyukina, T., Kuzyakov, Y., 2010. Model of apparent and real priming effects: linking microbial activity with soil organic matter decomposition Soil Biol. Biochem., 42, 1275-1283.

Bond, R.D., 1964. Influence of microflora on soil properties. II. Field studies on water repellent sands. Aust. J. Soil. Res., 2, 123-131.

Bond, R.D., Harris J.R., 1964. The influence of microflora on physical properties on soils. I. Effects associated with filamentous algae and fungi. Aust. J. Soil. Res., 2, 111-122.

Bossio, D.A., Scow, K.M., Gunapala, N., Graham, K.J., 1998. Determinants of soil microbial communities: effects of agricultural management, season, and soil type on phospholipid fatty acid profiles. Microb. Ecol., 36, 1-12.

Brockett, B., Prescott, C., Grayston, S., 2012. Soil moisture is the major factor influencing microbial community structure and enzyme activities across seven biogeoclimatic zones in western Canada. Soil Biol. Biochem., 44 (1), 9-20.

Cerdà, A., Schnabel, S., Ceballos, A., Gómez-Amelia, D., 1998. Soil hydrological response under simulated rainfall in the Dehesa land system (Extremadura, SW Spain) under drought conditions. Earth Surf. Processes Landforms, 23, 195-209.

Coelho, C.O.A., Laouina, A., Regaya, K., Ferreira, A.J.D., Carvalho, T.M.M., Chaker, M., Naafa, R., Naciri, R., Boulet, A.K., Keizer, J.J., 2005. The impact of soil water repellency on soil hydrological and erosional processes under Eucalyp- tus and evergreen Quercus forests in the Western Mediterranean. Aust. J. Soil Res., 43, 309-318.

DeBano, L.F., 2000. Water repellency in soils: a historical overview. J. Hydrol., 231-232, 4-32.

Doerr, S.H., Shakesby, R.A., Walsh, R.P.D., 2000. Soil water repellency: its causes, characteristics and hydrogeomorphological significance. Earth-Sci. Rev., 51, 33-65.

Federle, T.W., 1986. Microbial distribution in soil. In: Megusar, F., Gantar, M. (Eds.): Perspectives in Microbial Ecology. Slovene Society for Microbiology, Ljubljana, pp. 493-498.

Frostegåard, A., Baath, E., Tunlid, A., 1993. Shifts in the composition of soil microbial communities in limed forests as revealed by phospholipid fatty acid analysis. Soil Biol. Biochem., 25, 723-730.

Garcia-Pausas, J., Paterson, E., 2011. Microbial community abundance and structure are determinants of soil organic matter mineralisation in the presence of labile carbon. Soil Biol. Biochem., 43, 1705-1713.

Gömöryová, E., Ujházy, K., Martinák, M., Gömöry D., 2013. Soil microbial community response to variation in vegetation and abiotic environment in a temperate old-growth forest. Appl. Soil Ecol., 68, 10-19.

Graystone, S.J., Vaughan, D., Jones, D., 1996. Rhizosphere carbon flow in trees, in comparison with annual plants: the importance of root exudation and its impact on microbial activity and nutrient availability. Appl. Soil Ecol., 5, 29-56.

Hackl, E., Pfeffer, M., Dona, C., Bachmann, G., ZechmeisterBoltenstern, S., 2005. Composition of the microbial communities in the mineral soil under different types of natural forest. Soil Biol. Biochem., 37, 661-671.

Hallett, P.D., 2007. An introduction to soil water repellency. In: Gaskin, R.E. (Ed.): Proc. 8th Int. Symp. Adjuvants for agrochemicals. Hand Multimedia, Christchurch, New Zealand, 13 pp. ISBN 978-0-473-12388-8.

Högberg, M.N., Högberg, P., Myrold, D.D., 2007. Is microbial community composition in boreal forest soils determined by $\mathrm{pH}, \mathrm{C}$-to-N ratio, the trees, or all three? Oecologia, 150, 590-601.

King, P.M., 1981. Comparison of methods for measuring severity of water repellence of sandy soils and assessment of some factors that affect its measurement. Aust. J. Soil Res., 19, 275-285.

Lichner, L', Capuliak, J., Zhukova, N., Holko, L., Czachor, H., Kollár, J., 2013. Pines influence hydrophysical parameters and water flow in a sandy soil. Biologia, 68, 1104-1108.

Lozano, E., Jiménez-Pinilla, P., Mataix-Solera, J., Arcenegui, V., Bárcenas, G.M., González-Pérez, J.A., García-Orenes, F., Torres, M.P., Mataix-Beneyto, J., 2013. Biological and chemical factors controlling the patchy distribution of soil water repellency among plant species in a Mediterranean semiarid forest. Geoderma, 207-208, 212-220.

Martínez-Zavala, L., Jordán-López, A., 2009. Influence of different plant species on water repellency in Mediterranean heathland soils. Catena, 76, 215-223.

Mataix-Solera, J., Arcenegui, V., Guerrero, C., Mayoral, A.M., Morales, J., González, I., García-Orenes, F., Gómez, I., 2007. Water repellency under different species in a calcareous forest soil in a semiarid Mediterranean environment. Hydrol. Proc., 58, 1254-1259.

Merilä, P., Malmivaara-Lamsa, M., Spetz, P., Stark, S., Vierikko, K., Derome, J., Fritze, H., 2010. Soil organic matter quality as a link between microbial community structure and vegetation composition along a successional gradient in a boreal forest. Appl. Soil Ecol., 46, 259-267. 
Mitchell, R.J., Hester, A.J., Campbell, C.D., Chapman, S.J., Cameron, C.M., Hewison, R.J., Pottsl, J.M., 2010. Is vegetation composition or soil chemistry the best predictor of the soil microbial community? J. Ecol., 98, 50-61.

Moore, G., Blackwell, P., 1998. Water repellence. In: Moore, G. (Ed.): Soil guide: a handbook for understanding and managing agricultural soils. Agriculture Western Australia Bulletin No. 4343, Perth, WA, pp. 53-63.

Moral García, F.J., Dekker, L.W., Oostindie, K., Ritsema, C., 2005. Water repellency under natural conditions in sandy soils of southern Spain. Aust. J. Soil Res., 43, 291-296.

Müller, K., Deurer, M., Newton, P.C.D., 2010. Is there a link between elevated atmospheric carbon dioxide concentration, soil water repellency and soil carbon mineralization? Agric. Ecosyst. Environ., 139, 98-109.

Nelson, D.V., Sommers, L.E., 1996. Total carbon, organic carbon, and organic matter. In: Sparks, D.L. (Ed.): Methods of Soil Analysis. Part 3: Chemical Methods. Soil Science Society of America, Madison, WI, pp. 539-579.

Nichols, P., Stulp, B.K., Jones, J.G., White, D.C., 1986. Comparison of fatty acid content and DNA homology of the filamentous gliding bacteria Vitreoscilla, Flexibacter, Filibacter. Arch. Microbiol., 146, 1-6.

Nicolau, J.M., Solé-Benet, A., Puigdefábregas, J., Gutiérrez, L., 1996. Effects of soil and vegetation on runoff along a catena in semi-arid Spain. Geomorphology, 14, 297-309.

Olsson, P.A., Bääth, E., Jakobsen, I., Söderström, B., 1995. The use of phospholipid and neutral lipid fatty acids to estimate biomass of arbuscular mycorrhizal fungi in soil. Mycol. Res., 99, 623-629.

Rillig, M.C., 2005. A connection between fungal hydrophobins and soil water repellency. Pedobiologia, 49, 395-399.

Robinson, D.A., Lebron, I., Ryel, R.J., Jones, S.B., 2010. Soil water repellency: a method of soil moisture sequestration in pinyon-juniper woodland. Soil Sci. Soc. Am. J., 74, 624634.

Roper, M.M., 2004. The isolation and characterization of bacteria with the potential to degrade waxes that cause water repellency in sandy soils. Aust. J. Soil Res., 42, 427-433.

Savage, S.M., Martin, J.P., Letey, J., 1964. Contribution of some soil fungi to natural and heat-induced water repellency in sand. Soil Sci. Soc. Am. J., 33, 405-409.

Soil Survey Staff, 2006. Keys to Soil Taxonomy. 10th ed. NRCS, Washington, DC.

Stevens, G.A., Tang, C.S., 1985. Inhibition of seedling growth of crop species by recirculating root exudates of Bidens pilosa L. J. Chem. Ecol., 11, 1411-1425.
Ter Braak, C.J.F., 1988. CANOCO - a FORTRAN program for canonical community ordination by (partial) (detrended) (canonical) correspondence analysis, principal components analysis and redundancy analysis (version 2.1). Technical Report LWA-88-02, GLW, Wageningen, 95 pp.

Thoms, C., Gattinger, A., Jacob, M., Thomas, F.M., Gleixner, G., 2010. Direct and indirect effects of tree species diversity drive soil microbial diversity in temperate deciduous forest. Soil Biol. Biochem., 42, 1558-1565.

Treseder K.K., Turner K.M., 2007. Glomalin in ecosystems. Soil Sci. Soc. Am. J., 71, 1257-1266.

Valladares F., Balaguer L., Martinez-Ferri E., Perez-Corona E., Manrique E., 2002. Plasticity, instability and canalization: is the phenotypic variation in seedlings of sclerophyll oaks consistent with the environmental unpredictability of Mediterranean ecosystems? New Phytol., 156, 457-467.

White, N.A., Hallett, P.D., Feeney, D., Palfreyman, J.W., Ritz, K., 2000. Changes to water repellence of soil caused by the growth of white-rot fungi: studies using a novel microcosm system. FEMS Microbiol. Lett., 184, 73-77.

White, C., Tardif, J.C., Adkins, A., Staniforth, R., 2005. Functional diversity of microbial communities in the mixed boreal plain forest of central Canada. Soil Biol. Biochem., 37, 1359-1372.

Wright, S.F., Upadhyaya, A., 1996. Extraction of an abundant and unusual protein from soil and comparison with hyphal protein from arbuscular mycorrhizal fungi. Soil Sci., 161, $575-586$

Zak, D.R., Holmes, W.E., White, D.C., Peacock, A.D., Tilman, D., 2003. Plant diversity, soil microbial communities, and ecosystem function: are there any links? Ecology, 84, 20422050.

Zelles, L., Bai, Q.Y., Ma, R.X., Rackwitz, R., Winter, K., Beese, F., 1994. Microbial biomass, metabolic quotient and nutritional status determined from fatty acid patterns and poly-hydroxybutyrate in agriculturally-managed soils. Soil Biol. Biochem., 26, 439-446.

Zornoza, R., Guerrero, C., Mataix-Solera, J., Scow, K.M., Arcenegui, V., Mataix-Beneyto, J., 2009. Changes in soil microbial community structure following the abandonment of agricultural terraces in mountainous areas of Eastern Spain. Appl. Soil. Ecol., 42, 315-323.

Received 26 October 2013 Accepted 18 February 2014 